\title{
DO ACESSO À CIÊNCIA E À INFORMAÇÃO
}

A ciência não é panacéia para os problemas da humanidade. Porém, devese reconhecer sua contribuição na sociedade do conhecimento, pelo potencial de respostas às questões e problemas dessa sociedade, possibilitando transformações necessárias, que podem levar a melhoria da qualidade de vida. Não esquecendo que, para a ciência chegar a propiciar a melhoria da qualidade de vida, pressupõese 0 atendimento às condições prévias, entre as quais pode-se destacar: estabelecimento e implementação de políticas científicas compatíveis com a realidade social; investimentos nas universidades e instituições de pesquisa; e priorização da educação como meta nacional.

A questão da Ciência hoje não está mais restrita aos meios científicos, existe uma ampla discussão dos diversos aspectos da ciência e de sua interface com a sociedade.

A ciência está acessível ao público em geral e a sociedade pode acompanhar seu desenvolvimento, pela divulgação de suas realizações por intermédio da mídia: impressa, televisiva e virtual, com destaque às questões cruciais que afetam diretamente a sobrevivência da humanidade, como as pandemias, o degelo dos pólos, a redução da camada de ozônio e o aumento dos gases de efeito estufa, sobre alterações do clima global, alterações dos ecossistemas pelo desequilibro ambiental. Há abundância de informação destas temáticas e outras que estão disponíveis para as diferentes faixas de público

Além disso, as tecnologias da comunicação e da informação (TIC's) influenciam as necessidades e usos de informação, de forma a criar novas demandas, sobretudo pelas facilidades de acesso.

Nesse cenário de novas e crescentes demandas, o profissional da informação pode atuar de forma decisiva, possibilitando que o acesso à informação se transforme numa prática social, torne-se de fato, de livre acesso ao cidadão; portanto, um direito de todos. 
Neste número da Revista Informação

\& Informação é apresentada uma gama variada de temáticas. Inicia com o artigo intitulado O objeto de estudo da Ciência da Informação: a morte do indivíduo, em que os autores, Luiz Fernando de Barros Campos e Ludmila Salomão Venâncio procuram mostrar, por meio de uma exposição epistemológica de metateorias, que as tendências atuais do campo da Ciência da Informação apontam para a premência de uma abordagem holística e interdisciplinar, que efetivamente integre o material e o social.

As autoras Lívia Aparecida Ferreira Lenzi e Ednéa Zandonadi Brambila abordam, no artigo Da informação, ciência e revolução científica: breve histórico e reflexões, questões da ciência e da revolução científica, do pensamento científico moderno, da construção do saber racional, da observação da realidade (empirismo) e da experimentação para chegar ao surgimento da Ciência da Informação.

Com o propósito de refletir sobre a construção de um currículo em sintonia com o projeto educativo frente ao cenário das mudanças tecnológicas, a autora Miriam de Albuquerque Aquino, no artigo $A$ construção do currículo em parceria com o projeto educativo, faz considerações para pensar as novas formas de aprendizagem.

No artigo $A$ catalogação como atividade profissional especializada e objeto de ensino universitário de Dulce Maria Baptista, a autora situa sua argumentação a partir da mudança ocorrida, no século $X X$, do paradigma do volume das coleções, ao acesso à informação, analisando os desdobramentos e perspectivas da catalogação em função dos avanços tecnológicos.

Por fim, na resenha produzida por Geraldina Porto Witter, a autora tece importantes considerações do livro resenhado.

Com certeza o leitor poderá adentrar nestas páginas virtuais e vislumbrar o potencial de conhecimento da ciência da informação.

Ana Esmeralda Carelli Membro do Comitê Editorial 